\title{
The Impact of Facilities and Service-Based Competition on Internet Services Provision in the Canadian Broadband Market
}

Accepted Author Manuscript. This paper was published as van Gorp, A., \& Middleton, C. (2010). The Impact of Facilities and Service-Based Competition on Internet Services Provision in the Canadian Broadband Market. Telematics and Informatics, 27(3), 217-230. doi: 10.1016/j.tele.2009.12.001

\begin{abstract}
A variety of studies have focused on the effect of competition in broadband markets on increasing broadband penetration rates. Few studies however have focused on the extent to which competition also results in innovation in the marketplace, as demonstrated by increased broadband speeds, and other improvements that provide value to broadband users. This paper considers the effectiveness of market competition as a means of encouraging broadband providers to offer innovative services that meet citizens' increasing needs for affordable high quality and high speed broadband connectivity. The study focuses on the provision of broadband services in Canada, a country where consumers were early adopters of broadband and where the policy environment has encouraged competition in the broadband market from its inception. Drawing on data from the OECD and the Canadian Radio-television and Telecommunications Commission (CRTC), the paper demonstrates that Canada's regulatory regime does not appear to be sufficient to enable a competitive marketplace that results in the provision of innovative broadband services.
\end{abstract}

Keywords: Canada, broadband Internet access, facilities-based competition, service-based competition, regulation, DSL 


\section{Introduction}

Around the world, countries are developing policies and infrastructure to allow their citizens and businesses to engage fully in the increasingly Internet-based, digital economy and the information society it engenders (International Telecommunication Union, 2009). As advanced content and entertainment services on the Internet increase the demand for bandwidth, there is a need to provide citizens with higher capacity networks (Analysys Mason, 2008; Broadband Stakeholder Group, 2007; California Broadband Task Force, 2008; Ezell, Atkinson, Castro, \& Ou, 2009; Falch \& Henten, 2008; OECD Directorate for Science Technology and Industry, 2008b). Therefore, it is widely agreed that broadband communication networks ${ }^{1}$ are a fundamental enabler of the digital economy, and that access to broadband networks is becoming a necessity (Brown, 2009; Department for Culture Media and Sport \& Department for Business Innovation and Skills, 2009; Department of Broadband Communications and the Digital Economy, 2009; Federal-State Joint Board on Universal Service, 2007; UNCTAD Secretariat, 2007).

How to best achieve access to high-capacity broadband networks has been topic of debate for many years. Previous research has demonstrated that competition among broadband providers is

${ }^{1}$ The most basic definition of a broadband network is one that provides speeds that are higher than those offered by dial-up connections. The OECD defines broadband connections as having speeds greater than 256 kilobits per second (Kbps or kbit/s) (OECD, 2009e). The Broadband Technology Opportunities Program in US defines broadband as "least $768 \mathrm{kbps}$ downstream and at least $200 \mathrm{kbps}$ upstream to end users" (National Telecommunications and Information Administration, 2009), Canada's Connecting Rural Canadians program defines broadband as download speeds of 1.5 megabits per second (Mbps or mbit/s) (Industry Canada, 2009a), and the UK's Digital Britain report calls for speeds of 2 Mbps (Department for Culture Media and Sport \& Department for Business Innovation and Skills, 2009). In contrast, Australia's proposed National Broadband Network is to deliver speeds of $100 \mathrm{Mbps}$ (Prime Minister of Australia, 2009), while Korea is planning for gigabit connectivity (1 Gbps) in its Ultra Broadband Convergence Network (KBS World, 2009). 
effective in increasing broadband penetration rates, but has focused to a lesser extent on whether competition also results in increased broadband speeds, and other improvements that provide value to broadband users. This paper considers the effectiveness of market competition as a means of encouraging broadband providers to offer innovative services that meet citizens' increasing needs for high quality, high speed, affordable broadband connectivity. In particular, the study focuses on the provision of broadband services in Canada, a country where consumers were early adopters of broadband and where the policy environment has encouraged competition in the broadband market from its inception. It explores the following research question: To what extent do service-based and facilities-based competition exist in the Canadian broadband market and how has the former affected the development of innovative broadband services?

The study draws on secondary data from the OECD and the Canadian Radio-television and Telecommunications Commission (CRTC), Canada's telecommunications regulator. The paper demonstrates that Canada's regulatory regime does not appear to be sufficient to enable a competitive marketplace that results in the provision of broadband connectivity that offers citizens choice and innovative services.

The paper begins with an overview of the telecommunications environment in Canada to set the context for the research, and then reviews the literature on competition in broadband markets. It outlines policy and regulation in Canada, and then in section 4 presents data that demonstrate that the market has not delivered consumer choice, or internationally competitive speeds and pricing for broadband connectivity. Section 5 considers why competition has not been effective in Canada. Section 6 finishes with conclusions. 


\section{Broadband Policy Developments and the Regulatory Environment in Canada}

As the early histories of broadband adoption were told, Canada was often identified as a global broadband leader (Frieden, 2005; Ovum, 2006; Wu, 2004). Canada's Rogers Communications was the first cable operator in the world to offer residential broadband service, beginning in late 1996. From 1997, when the OECD first began tracking broadband adoption rates, until 2004, Canada was a frontrunner in broadband uptake, ranked first or second in the OECD (OECD, 2009e). But by 2008, Canada had slipped to $10^{\text {th }}$ spot in the OECD rankings, falling behind many European countries (OECD, 2009d). Nevertheless, Canada's reputation as a broadband leader persists. Frequent mention is made of federal policies that encouraged connectivity (e.g. Atkinson, Correa, \& Hedlund, 2008; Bouras, Giannaka, \& Tsiatsos, 2009), and Canada's early regulatory practices have been emulated in other countries. ${ }^{2}$

Indeed, prior to 2006, the Canadian government actively promoted an "information society" agenda, attempting to develop infrastructure and services that would enable Canada to become the "most connected" country in the world (Chretien, 2000; Information Highway Advisory Council, 1996, 1997; Manley, 1999). Particularly notable in this regard was a 2001 taskforce recommendation for a multi-billion dollar investment in infrastructure, aimed at providing broadband services to "businesses and residents in every Canadian community by 2004" (National Broadband Task Force, 2001, p. 1). Although the recommended investments to achieve full broadband coverage were not made, the taskforce report was a catalyst for the Broadband for Rural and Northern Development (BRAND) and National Satellite Initiative (NSI) projects launched in 2002 and 2003 respectively, that extended broadband availability in rural and remote

${ }^{2}$ For example, in its proposed local loop unbundling regulation, the Dutch regulatory authority made explicit reference to Canadian regulation, citing that a sunset period of 5 year for mandatory unbundling would stimulate innovation and infrastructure investment (OPTA, 1999, section 31). 
communities (Industry Canada, 2005a, 2005b). Subsequently, in 2006 the Telecommunications Policy Review Panel recommended the development of a Ubiquitous Canadian Access Network (U-CAN). This network was to ensure the availability of broadband in parts of the country where commercial providers were unlikely to provide service (Telecommunications Policy Review Panel, 2006). This network was to be in place by 2010, but until 2009 the Federal Government had made no commitments to enable this outcome. Thus, the last couple of years demonstrate a limited role of government in stimulating broadband provision.

Nevertheless, in the 2009 Federal budget, the government announced the Connecting Rural Canadians project, with an investment of $\$ 225$ million (CAD) to extend the reach of broadband networks at speeds of 1.5 Mbps to unserved areas (Industry Canada, 2009c). The project will fund up to $50 \%$ of project costs (Industry Canada, 2009b). While any investment in the further development of broadband infrastructure will be welcomed by unserved communities, this is a modest investment as compared to for example the $\$ 4.7$ billion U.S. Broadband Technology Opportunities Program as part of the American Recovery and Reinvestment Act (NTIA, 2009). However, it does demonstrate a further commitment to infrastructure development to serve the $6 \%$ of Canadian households that do not have access to fixed line broadband services.

While the aforementioned government policies focus on bringing connectivity to unserved areas, the Canadian Radio-television and Telecommunications Commission (CRTC), Canada's telecommunications regulator, is charged with stimulating competition in Canada's broadband market. Mandated by government, and following the recommendations of the Telecommunications Policy Review Panel, the CRTC operates under a directive to "rely on market forces to the maximum extent feasible as the means of achieving the telecommunications policy objectives" (Governor General in Council, 2006). Where regulation is deemed to be 
necessary, it is to "interfere with the operation of competitive market forces to the minimum extent necessary to meet the policy objectives" (Governor General in Council, 2006). Thus, as the CRTC explains: "[...] pursuant to the Telecommunications Act, the Commission strives to ensure the provision of reliable and affordable telecommunications services of high quality accessible to both urban and rural area customers, to foster facilities-based competition, to provide incumbents with incentives to increase efficiencies and be more innovative, and to adopt regulatory approaches, where necessary, that impose the minimum regulatory burden possible" (CRTC, 2009a, p. 5). Even though the reliance on market forces is common across many countries, the CRTC's explicit 'laissez faire' approach seems to go further, as can be observed by the reiteration of this approach in a vast amount of the CRTC's documents. Nevertheless, as Moll and Shade (2008) observe, this free market approach to telecommunications regulation has its weaknesses, and various groups are calling for a more interventionist approach (Anderson, 2009; Moll, 2008).

Interesting to note in this regard however, is that free market principles do not apply to foreign market entry. Even though the Telecommunications Act provides a framework that is to stimulate competition and universal access, in apparent contradiction to the CRTC's explicit laissez faire mandate, articles 7D and 7E of the Act promote "ownership and control of Canadian carriers by Canadians", and "the use of Canadian transmission facilities for telecommunications within Canada and between Canada and points outside Canada" (Canada, 1993, p. 4). This makes Canada one of only three countries in the OECD in which foreign ownership restrictions apply to all players in the market (OECD, 2009f). At least $80 \%$ of the board of directors of both fixed line and wireless network operators that operate in regulated bands must be Canadian, and at least $80 \%$ of voting shares must be owned by Canadians (Canada, 1993). 
In sum, Canada's policy approach allows for interventions when needed to reach underserved areas, while Canada's regulatory authority seeks to stimulate competition, with the dominant means of achieving competition being reliance on market forces. In the section below, the role of competition in global broadband markets is examined, and the state of competition in the Canadian market is assessed.

\section{The Role of Competition in Promoting Broadband Penetration}

The OECD started tracking broadband adoption rates in the late 1990s, and by 2001 recommended that the best way to encourage broadband access was by spurring infrastructure competition (OECD Directorate for Science Technology and Industry, 2001). This focus on fostering competition as a means to increase innovation and investment in the broadband market continues (OECD, 2008b; OECD Directorate for Science Technology and Industry, 2003b, 2008b), supported by evidence that facilities-based competition in particular has been effective in increasing broadband penetration in OECD countries (Distaso, Lupi, \& Manenti, 2006; Polykalas \& Vlachos, 2006).

With policy regimes that promote market-based approaches to infrastructure development, it is expected that competition in the market will drive innovation. For example, competition could result in increased performance of DSL and cable network infrastructures as an interim step in a transition to end-to-end fiber networks. With DOCSIS 3.0 technologies, cable networks can provide 100 Mbps or faster symmetrical connections, and VDSL2 (very high speed DSL) connections can offer up to 50 Mbps symmetrical service (OECD Directorate for Science Technology and Industry, 2008a). While fiber networks are seen as the most "future-proof" (Computer Science and Telecommunications Board, 2002; Reynolds, 2009), upgraded DSL and 
cable networks can certainly meet the needs of most broadband consumers over the next few years, and a competitive broadband market should deliver these upgrades.

\subsection{Types of Competition: Facilities-Based and Service-Based}

High speeds, low prices and innovative Internet access services are typically found in areas where consumers have a variety of choices for broadband (OECD, 2008b). To stimulate variety, regulatory authorities act to create competitive environments in which operators have incentives to innovate and invest in their networks (de Bijl \& Peitz, 2008). One of the most basic means to achieve a competitive environment is to promote both facilities- and service-based competition, which are likely to lead to a variety of service packages and pricing structures, as well as high levels of customer service. Facilities-based competition ${ }^{3}$ refers to competition arising as the result of availability of more than one type of infrastructure connecting homes. To date, most facilities-based competition has been between DSL and cable infrastructures (Organisation for Economic Co-operation and Development, 2009). Fiber networks are gaining market share in a few countries (OECD, 2009g), but in others, the path from existing cable and DSL infrastructures to higher capacity, 'next generation' networks is not yet clear. Service-based competition $^{4}$ on the other hand occurs when more than one company offers Internet access services over a single last mile infrastructure. Typically, service-based competition is created by unbundling the local loop, requiring the incumbent telecommunications operator to allow its competitors to use its existing last mile copper infrastructure (i.e. the fixed line telephone network), over which DSL services are provided to residential customers.

Facilities-based competition is believed to better stimulate innovation and competition than

\footnotetext{
${ }^{3}$ This is also referred to as platform competition, infrastructure competition or inter-modal competition.

${ }^{4}$ This may be referred to as intra-modal competition.
} 
service-based competition, resulting in increased broadband penetration rates (e.g. Baranes \& Bourreau, 2005; Bourreau \& Dogan, 2004; Denni \& Gruber, 2007; Distaso et al., 2006; OECD, 2008b). Of course, access to more than one type of infrastructure to the home provides the customer with more choice, and also enables competition where each provider is able to determine the services it wants to provide over its infrastructure. In contrast, with service-based competition, a competitor leasing access to the last mile offers services are to a greater or lesser extent determined by the incumbent (depending on the particular agreement in place), which limits the potential for the entrant to innovate on the basis of speed, quality or pricing (e.g. Bourreau \& Dogan, 2004; Christodoulou \& Vlahos, 2001; Hartley, 2008).

Nevertheless, although facilities-based competition is thought to be desirable, it tends to be difficult to achieve. Given the large upfront investments required for a market entrant to roll out new infrastructure, an entrant needs to immediately generate significant traffic volumes and have customers concentrated around particular areas in order to be profitable or break even (e.g. Christodoulou \& Vlahos, 2001). Hence, service-based competition is seen as a potentially fruitful alternative: entry costs are much lower when entrants lease infrastructure or resell the incumbent's services (Christodoulou \& Vlahos, 2001). Further, as the "ladder of investment" or “stepping stone" theory suggests (Cave, 2006; European Regulators Group, 2005), service-based competition has the potential to lead to facilities-based competition, by allowing entrants to gradually invest and acquire capital assets, while simultaneously expanding their customer base and generating revenues that can be used for further investment (Cave, 2006). It is therefore no surprise that despite being considered as a "second-best" alternative, unbundling policies have been implemented to introduce service-based competition into broadband markets in 29 of the 30 OECD markets (OECD, 2009f). 
However, paradoxically, service-based competition also bears the risk of actually deterring facilities-based competition and further innovation and investment in the existing single infrastructure (Bouckaert, van Dijk, \& Verboven, 2008; Quast, 2008; Quigley, 2004): with the incumbent providing attractive access provisions (e.g. relatively low prices for unbundled loops), incentives for a new provider to roll out new infrastructure are diminished. Thus, due to the potentially mixed effects of service-based competition as well as the significant challenges surrounding facilities-based entry, a mix of both service-based and facilities-based competition is often pursued in order to best stimulate investment by both incumbent and new entrants (CLECs) (Christodoulou \& Vlahos, 2001) and to encourage broadband penetration (Picot \& Wernick, 2007).

In the section that follows, we discuss the nature of competition evident in global broadband markets, and identify the specific market conditions present in Canada.

\subsection{Potential for Facilities and Service-Based Competition in Canada}

\subsubsection{Facilities-Based Competition}

The most common broadband networks with nearly nationwide footprint across countries are fixed telecommunications networks that enable DSL provision. Facilities-based competition to DSL service includes wireless networks, fiber to the home, and cable. Wireless technologies such as third generation and higher mobile technologies (e.g. UMTS, HSPA, LTE), Wi-Fi and WiMAX are sometimes promoted as alternatives for fixed broadband networks (e.g. de Bijl \& Peitz, 2008), but they have yet to gain significant market share. Mobile broadband services are becoming more popular (International Telecommunication Union, 2009), but they do not always

offer competitive prices and speeds when compared to fixed line access (International 
Telecommunication Union, 2008). In Europe in 2007 only 2\% of broadband connections were provided by mobile services (Huigen \& Cave, 2008). In Canada the mobile market is particularly poorly developed. For example, in 2008 , less than $75 \%$ of the Canadian population subscribed to mobile voice services (CRTC, 2009a) - among the lowest level of uptake in the OECD. Mobile wireless internet access is available from telco and cable internet service providers, but rates are higher than for fixed line access and take up is low. Thus, mobile networks are not (yet) a serious alternative Internet access technology for Canadians. ${ }^{5}$

Fiber to the home (FTTH) networks are increasingly popular due to their very high speeds (up to $100 \mathrm{Mbps}$ or higher, with the potential for symmetrical download and upload speeds). Already widely available in Japan and Korea, fiber networks require high upfront investments (Analysys Mason, 2008; OECD Directorate for Science Technology and Industry, 2008a) and are being rolled out only on a small scale elsewhere. In the US, where $4 \%$ of broadband subscribers had fiber connections in late 2008, Verizon has been leading the deployment of FTTH networks (Verizon Communications, 2008, 2009). Among the EU15, the average market share for fiber in late 2008 was just $1 \%$, while in Canada the market share was even less than $1 \%$ (OECD, 2009g).

Recently, several countries have announced plans for significant investment in national fiber broadband networks (see for example Infocomm Development Authority of Singapore, 2008; KBS World, 2009; Prime Minister of Australia, 2009; Troulos, 2008), or the development of national broadband strategies (Department for Culture Media \& Sport \& Department for Business Enterprise \& Regulatory Reform, 2009; Federal Communications Commission, 2009) but Canada is not among them. There are however a few small operational FTTH deployments

${ }^{5}$ At the time of writing, Canadian mobile operators Bell and Telus had just switched on their HSPA network, providing new competition for fixed line broadband services across the country. 
(see for example Ménard, 2006), and in mid-2009 the incumbent in Atlantic Canada, Bell Aliant, announced plans to provide FTTH service in two New Brunswick cities (Bell Aliant, 2009).

Therefore, to date the most common competitive facilities-based infrastructure is a cable network. But in many countries cable connects just a fraction of homes (OECD Directorate for Science Technology and Industry, 2003a). In the EU, for instance, only about $30 \%$ of homes are connected to a cable network (Huigen \& Cave, 2008). Canada however has a nearly nation-wide cable network that reaches more than $90 \%$ of Canadian households. This means that most Canadians have a choice of DSL or cable when selecting a broadband service provider. ${ }^{6}$ Indeed, market shares of these competing technologies are rather equally divided, with cable adoption at approximately 55\% versus $45 \%$ for DSL (CRTC, 2009a). Thus, as measured by the mere presence of alternative last mile infrastructures, the Canadian market could be argued to have facilities-based competition. Nevertheless, measuring competition by market outcomes this is seemingly not the case as will be further discussed in section 4 . Next we first turn to a discussion of the status of service-based competition.

\subsubsection{Service-Based Competition}

Service-based competition exists predominantly on copper (DSL) networks, but it is also possible over cable networks. As noted, cable networks typically account for the main competitive infrastructure to DSL platforms, but across the globe significantly less emphasis has been placed on regulating third party access to cable networks (Braverman \& Frappier, 2003; Schwarz, 2007). This is likely related to the limited global availability of cable networks of national scale.

\footnotetext{
${ }^{6}$ Approximately $6 \%$ of Canadian households are not served by a fixed line broadband provider. $84 \%$ of households have access to DSL connections, and 80\% have access to cable broadband (CRTC, 2009a). 
Canada is unusual in that the regulator has enabled service-based competition on two platforms, cable and DSL. The CRTC mandated incumbent Canadian cable operators (cablecos) to provide third party access to their networks in 1999 (CRTC, 1999; Menard \& Denton, 1999). Yet despite the CRTC's mandate for open access to cable networks, third party access in Canada has not always been easy to obtain (Canadian Association of Internet Providers, 2003), with access seekers resorting to petitioning the regulator to enforce the access regulations (CRTC, 2003, 2004). Tariffs are published that set out the conditions for service provision (CRTC, 2006), but independent ISPs offering cable broadband services do not have significant market share (CRTC, 2008a).

In Canada, local loop unbundling of the fixed copper network was initiated in 1997, when the CRTC decided to allow Competitive Local Exchange Carriers (CLECs) to request an Incumbent Local Exchange Carrier (ILEC) ${ }^{7}$ to provide various unbundled facilities (CRTC, 1997). The CRTC concluded that essential facilities should be subjected to mandatory unbundling and mandated pricing. Essential facilities were defined as facilities that (1) are monopoly controlled; (2) are needed by new entrants as input in order to provide services; and (3) cannot be duplicated either economically or technically (OECD, 2002). For instance, local loops in small rural and urban areas were defined as essential.

In addition to unbundling of essential facilities, a sunset clause in the same CRTC decision (97-8) mandated that near-essential facilities (e.g. low cost loops in low cost bands, often found in large urban areas) be unbundled for a period of five years at the same price as essential facilities (OECD, 2002). Sunset clauses were proposed by regulators in some countries to address the concern that local loop unbundling could delay investment that leads to facilities-

${ }^{7}$ In Canada, there are several large incumbent telecommunications carriers (Telus, SaskTel, MTS, Bell, Télébec, Bell Aliant), each with its primary operations in a specific geographic sector of the market. 
based competition. These clauses set rules for a specific period of time, for instance stating a fixed period in which line-sharing would be mandatory and regulated. After the time period expires, the clause no longer applies, for example removing the regulatory requirement to offer line-sharing, or changing the pricing structure for access to the incumbent's infrastructure. The rationale behind this approach is to stimulate competitors to enter the market, gain necessary operational experience and market share, and develop the financial and technical capacity to rollout infrastructure-based competitive services themselves. As such, a sunset clause should stimulate, or lead to, facilities-based competition (see e.g. Bourreau \& Dogan, 2004).

The sunset clause in the Canadian market did not achieve the desired results, with only $4 \%$ of local loops unbundled by 2000 (OECD Directorate for Science Technology and Industry, 2003c). So to further stimulate local loop unbundling, in 2000 the CRTC decided to extend co-location rights to companies that were not registered as public telecommunication operators (PTOs), which was previously mandatory (CRTC, 2001a; OECD, 2002). Nevertheless, pricing structures and co-location problems continued to limit competition in the DSL market (OECD, 2002). Even though the CRTC set fixed prices for access to unbundled local loops, the 2001 decision to lower prices by $25-30 \%$ was indicative of excessive initial pricing (CRTC, 2001b; OECD, 2002). Moreover, initially, as per the 1997 decision, new entrants to the market (CLECs) did not get wholesale prices but instead relied on retail prices set by the CRTC (OECD, 2002). Hence, there was little incentive to enter the market as new entrants could not provide competitive prices to their customers. Additionally, various decisions in 2001 served to reduce new entrants' costs for co-location (OECD, 2002).

These early difficulties in developing and implementing appropriate regulatory measures are not specific to Canada however. Local loop unbundling requires significant coordination 
between the incumbent and the entrant, such as for billing, ordering, fault handling, and in negotiating pricing, co-location and spectrum management agreements (Christodoulou \& Vlahos, 2001; OECD Directorate for Science Technology and Industry, 2003c). Therefore, even though incumbents are required to open their networks to competitors, opportunities abound for incumbents to delay service-based competition, for example through delaying the provision of actual physical co-location space or providing poor quality or non-functioning lines. Indeed, problems of this nature have been reported in numerous countries (e.g. Bourreau \& Dogan, 2004; Van Gorp, Maitland, \& Hanekop, 2006; Whalley \& Curwen, 2008).

In similar vein, the subsequent history of third party DSL access in Canada is characterized by frequent requests from market entrants to the CRTC to enforce its orders, coupled with responses from the incumbents explaining why their refusals to comply are legitimate. Similar to their counterparts in other countries, incumbents seek to delay access, while competitors attempt to expedite access. ${ }^{8}$ This tug of war continues.

In Canada, the CRTC's regulations mandate service-based competition on both DSL and cable platforms. Although the implementation of these policies continues to generate friction between market entrants and the telco incumbents and cablecos whose infrastructures they are accessing, a number of $\operatorname{ISPs}^{9}$ have developed retail broadband businesses as service-based competitors in the Canadian broadband market. Nevertheless, for DSL provision very few ISPs co-locate while the majority resell the incumbents' wholesale product. Resale of wholesale products is particularly prone to control by incumbents; as revealed by the CRTC's Telecom

${ }^{8}$ A review of the decisions and orders archived on the CRTC's website highlights this constant struggle between the incumbents, competitors and the regulator. See http://www.crtc.gc.ca/eng/dno.htm. The July 2009 CRTC hearings on Internet traffic management practices of Internet service providers also revealed the conflicted relationship among the regulator, incumbents and market entrants (CRTC, 2008b).

${ }^{9}$ Service-based competitors in the Canadian retail broadband market include Cybersurf, Execulink, Primus, TekSavvy and Xittel. 
Order 2009-111 (CRTC, 2009d) that now requires the incumbents to provide "wholesale aggregated ADSL services" at the same speeds as the ILECs offer to their own retail customers. The order is currently being challenged however by incumbents Bell and Telus (CRTC, 2009b).

\section{Does Competition Encourage Innovation? Assessing the Canadian Broadband Market}

Given Canada's nearly nationwide availability of both cable and DSL infrastructure, the Canadian broadband market could be a competitive one. DSL and cable broadband providers entered the market early in Canada, and as a result Canadians living in many urban centers have had the choice of two facilities-based service providers for 10 or more years.

However, competition among broadband providers is expected to deliver higher quality, cheaper and faster Internet access services to consumers (OECD, 2008b). This section addresses the question of whether the presence of facilities- and service-based competitors in the Canadian residential broadband market has been sufficient to foster such innovations and enable real choice for consumers. OECD ${ }^{10}$ and CRTC data are used to assess broadband offerings in Canada. Arguably, the most common indicator of competition is the existence of a multiplayer environment (Li, Qiang, \& Xu, 2001), which suggests limited market power for firms. Market power is traditionally measured by market concentration (Borenstein, Bushnell, \& Knittel, 1999). Hence, we will start with a brief review of market concentration in the Canadian ISP market. Next, as competition is believed to be favorable to innovation (Van Cuilenburg \& Slaa, 1995),

${ }^{10}$ These data have been criticized for underestimating broadband uptake and some believe that a ranking approach is not useful (see for example Beard, Ford, \& Spiwak, 2009; Ford, Koutsky, \& Spiwak, 2007; Market Clarity, 2007). It is also noted that the OECD's Canadian statistics do not always correlate with those from the CRTC. However, for the purposes of this paper, the OECD offers consistent international data on residential broadband uptake, pricing and network quality, showing trends over several years and allowing for an understanding of the relative strengths and weaknesses of broadband offerings in Canada. 
we discuss innovation indicators; in particular pricing, speed and quality. These fall under the two categories of innovation: process innovation and product innovation. The former refers to innovation in methods to more efficiently make goods and services - in the telecom industry often observed in lower prices, whereas the latter refers to new choices for information and communication (Van Cuilenburg \& Slaa, 1995), which may be seen as differentiation in products -- in Internet access services usually observed in increased speeds and quality of service.

\subsection{Market Concentration}

In Canada, approximately 500 Internet Service Providers (ISPs) serve the business and residential markets (CRTC, 2009a). The exact number of ISPs providing residential services is unknown, but estimated to be much lower due to the lower profitability of ISPs targeting residential versus business customers.

Although not uncommon, the Canadian market is highly concentrated. The five largest retail ISPs accounted for 76\% of overall Internet access revenues in 2008 (CRTC, 2009a). Further, even though only $9 \%$ of Canada's ISPs are incumbent service providers that own fixed line (telephone) infrastructure, and another $18 \%$ are cable companies with their own infrastructure, collectively these incumbent telcos and cablecos serve $92 \%$ of residential customers, including 94.5\% of broadband subscribers (CRTC, 2009a), and generate $88 \%$ of Internet access revenues.

Incumbent ISPs furthermore continue to gain market share: In 2008, non-incumbent infrastructure owners together generated $12 \%$ of internet access revenues, down from $14 \%$ in 2006, and from as much as 23\% in 2003 (CRTC, 2008a, 2009a). Additionally, service-based competition has not established a strong hold for broadband resellers in the market: although the total number of subscribers to non-incumbent, non-cable broadband services increased in 2008, it was only the first increase since 2001 (CRTC, 2009a). This is a strong indicator that service- 
based competition has not established a strong hold in the marketplace in the early days of broadband Internet provision.

\subsection{Prices}

International comparisons reveal that Internet access prices in Canada are on the high end. In late 2008 Canada ranked $27^{\text {th }}$ out of 30 countries (the cheapest country is ranked 1 st) for average monthly broadband prices per advertised Mbps (OECD, 2009b). A recent study by the Berkman Center for Internet \& Society (2009) also reports that even though Canada is often regarded as a high performer, prices in Canada are typically high, while speeds are on the lower end. Nevertheless, not everybody agrees; a recent report by Mark H. Goldberg \& Associates Inc. (2009), commissioned by Canada's incumbent telcos and cable companies, indicates that Canada provides the second lowest prices for entry level service offers, and that overall Canada remains a broadband leader.

When we compared prices of Internet access packages in Canada, the U.S., the Netherlands and Sweden, of 3 randomly chosen, yet major broadband providers, it was found that Canada is on the higher end of prices ${ }^{11}$. For the cheapest service Canada, according to this comparison, scores middle range. For example, of three major ISPs in Canada the cheapest service costs USD \$21 (including taxes) monthly for DSL service of maximum 2 Mbps download speed. In Sweden the cheapest service of 3 major providers costs USD \$14 for $500 \mathrm{Kbps}$. In the U.S. for USD \$21 for $768 \mathrm{Kbps}$. Finally, in the Netherlands the cheapest service costs USD \$29 for 4Mbps. It is interesting to note that in the Netherlands the cheaper services tend to be more expensive than in other countries, but also higher entry level speeds are provided. See also Table 1.

${ }^{11}$ The Netherlands and Sweden are chosen because they represent countries with high broadband uptake as well as significant investment in next generation networks, whereas the U.S. and Canada are mid-range countries according to OECD statistics. Prices were compared in September 2009 and include VAT. 


\section{$<$ Table 1 about here $>$}

Nevertheless, when looking at the faster service, one finds that in Canada the three incumbents' highest speeds are at 16, 25, and 50 Mbps download speeds. While 16 Mbps costs USD \$52, the 25 Mbps service costs USD \$102 and the 50 Mbps service even costs as much as USD \$158. In the U.S. Comcast offers 50Mbps download speed for USD \$105 (including taxes), while in Sweden speeds up to 50 Mbps can be obtained for USD \$57 and the Netherlands 60 Mbps download speed can be obtained for USD \$58. In Sweden and the Netherlands speeds up to, or even higher, than 100 Mbps download are advertised, whereas in Canada and the U.S. it is not common for speeds offered by incumbents to go above $50 \mathrm{Mbps}$, and for those high speeds, the costs are significantly higher. An exception however in Canada is Shaw's offering of 100 Mbps service in Saskatchewan (available for approximately USD \$140).

In contrast to these findings and OECD numbers, based on data collected in early 2009, the CRTC concludes that "Canada reflects a median price point for medium- and high-use [broadband] baskets" (CRTC, 2009a, p. 251), when compared to the US, the UK, France and Australia. Applying the OECD's method of comparing prices on the basis of offered speeds to the CRTC data however show that Canadian prices are twice those in the UK and France, 60\% higher than Australia, and marginally cheaper than the US. A report by Mark H. Goldberg \& Associates Inc. (2009), commissioned by Canada's incumbent telcos and cable companies, even indicates that in Canada provides the second lowest prices for entry level service offers.

Of course, prices for certain Internet access speeds do not stand alone and are difficult to compare. Broadband subscriptions may come with extras such as virus protection, technical support, and access to specialized content. Pricing may or may not include installation and modem costs, and may depend on introductory offers, the length of contract and/or whether the 
service is bundled with other services.

Even though one-on-one comparisons are difficult to make, Canada does tend not to score well on many of these aspects. For example, in European countries typically there are no data limits (download caps), while in Canada lower speed services in particular frequently come with significant data limits. Indeed, Canada is only one of four countries in the OECD where download caps were imposed on all the service plans studied by the OECD (OECD, 2009c). Although average Canadian bitcaps are the most generous in the OECD, large providers like Bell are reducing, rather than increasing, the caps for new users (Bode, 2009). Despite all this evidence, the CRTC believes that prices for fixed line communications services in Canada compare "favourably" to other countries, including wired broadband Internet access services in which Canada comes out "mid-range" (CRTC, 2008a, p. v).

\subsection{Speed}

Download speeds in Canada also seem to be on the lower side. In late 2008, Canada ranked $25^{\text {th }}$ among the 30 OECD countries in download speeds, dropping from $15^{\text {th }}$ position in 2007. In $2008,76 \%$ of Canadian broadband customers subscribed to services advertised as providing download speeds of 1.5 Mbps or higher. 59\% subscribed to services with advertised speeds of 5 Mbps and higher, and only 9\% chose speeds of 10 Mbps or higher (CRTC, 2009a). While the speeds of Canadians' broadband connections have been increasing over time, on an international basis these speeds are low.

Further, the OECD reports that at $6.2 \mathrm{Mbps}$ the average advertised download speed in 2008 dropped from 7.8 Mbps in 2007, at the same time as the OECD average increased from 13.7 Mbps to 17.4 Mbps (OECD, 2008a, 2009a). According to the CRTC, in Canada, cable networks are "typically [...] marketed as offering download speeds of anywhere from 5 Mbps to 20 Mbps" 
(CRTC, 2008a, p. 246, 247). The CRTC does note that there are countries providing significantly higher speeds, but does relate this to population density in cities. In 2008 the CRTC noted that Japan, "with its heavy concentration of fibre to the home and densely populated cities is able to offer broadband speeds averaging 93.7 Mbps", and that South Korea has "average advertised speeds of 43.4 Mbps”.

And indeed, while in many countries telcos and cablecos are upgrading their networks, in Canada consumers are not yet benefitting from network upgrades. For example, in both the US and the Netherlands cable companies are rapidly upgrading their infrastructure to provide consumers with speeds of 50 to $100 \mathrm{Mbps}$, in response to the rollout of fiber to the home networks (Higginbotham, 2009; Van Gorp \& Middleton, 2009). Faster cable connections are not yet common in Canada, although upgraded services are becoming available in the major markets. DSL connections, even those provisioned with ADSL2+ or VDSL (a fiber to the node configuration) cannot match the speeds of upgraded cable or fiber to the home networks (OECD Directorate for Science Technology and Industry, 2008a). It is difficult to find information on the numbers of Canadian DSL subscribers who have access to faster DSL connections, but the OECD data on download speeds suggest that even where faster DSL and cable connections are available to Canadians, they have not yet been widely taken up.

\subsection{Quality of Service}

When a customer subscribes to a particular Internet access service, the speed of service subscribed to is a maximum speed. Customers rarely achieve the maximum advertised speeds, for reasons including the distance from the telephone exchange (for DSL) and contention among customers for bandwidth. Speeds may also vary with time of day (Epitiro, 2009; Ofcom, 2009). Failure to receive advertised speeds is commonplace, but in Canada, as in the U.S., Internet 
throttling is an additional key concern for consumer groups and independent ISPs. ${ }^{12}$ The CRTC defines throttling "as slowing down the transfer of rates of traffic by delaying certain data packets at certain points in the network" (CRTC, 2008b). In Canada, some Internet service providers reduce the speeds of peer-to-peer $(\mathrm{P} 2 \mathrm{P})$ traffic to as low as $80 \mathrm{Kbps}$, with one major ISP throttling all P2P traffic between 4:30 pm and 2 am daily and another throttling P2P uploads at all times (CRTC, 2009e).

Throttling does not only affect these ISPs' own retail customers, but also the customers of ISPs providing DSL wholesale broadband service through Bell Canada. In 2008, the Canadian Association of Internet Providers (CAIP) asked the CRTC to order Bell Canada to "cease and desist from "throttling" wholesale DSL services (CRTC, 2008c). The request was declined, but CAIP has filed an appeal to this decision (The Consumers' Association of Canada et al., 2009). Following CAIP's application, the CRTC initiated a consultation process ${ }^{13}$ for the purposes of reviewing "Internet traffic management practices of Internet service providers" (CRTC, 2008b). Hearings were held in July 2009 and revealed a diversity of practices among the dominant ISPs. ${ }^{14}$ These revelations angered retail and wholesale customers and consumer advocates, as they provided tangible evidence that ISPs intentionally compromise the quality of their customers' network access.

After its review of the Internet traffic management practices of Internet service providers, the CRTC decided in October 2009 to require ISPs to provide their customers with clear information on their traffic shaping practices, and encourages the use of economic measures (e.g. tiered

12 See for example online campaigns in favor of network neutrality, at http://saveournet.ca and http://www.savetheinternet.com.

${ }^{13}$ In the notice, and in light of its 'laissez faire' approach, the CRTC points out its limited role in regulating retail Internet services, but however does indicate it is empowered to do so might it be deemed necessary.

${ }^{14}$ Transcripts are available online at http://www.crtc.gc.ca/eng/transcripts/2009/index.htm. 
pricing structures) before technical measures like traffic shaping (CRTC, 2009e).

Of course, the request of independent ISPs to the CRTC for incumbents to stop throttling their service, is indicative of significant control of the latter over the former in wholesale DSL service, and thus highlights a key problem to service-based competition.

\subsection{Summary}

This section has provided an assessment of the current status of broadband services in terms of market concentration price, speed, and quality of service. It is found that the extent to which service-based and facilities-based competition in the Canadian broadband market have resulted in the development of innovative Internet access services is limited. Table 2 summarizes the data presented in this section.

\section{$<$ Table 2 about here $>$}

\section{Discussion}

As the literature suggests, the presence of alternative last mile technologies with a (near) nationwide footprint in the Canadian broadband market from its inception may have been a reason for Canada's early lead in broadband uptake (see for example Polykalas \& Vlachos, 2006). However, the data presented here suggest that, despite the co-existence of two alternative last mile infrastructures with nationwide footprint, competition in the market is not robust, as Canada's major (incumbent) players have been slow in providing their customers with access to offer higher speeds, lower prices or better quality of service.

Testimony before the CRTC's Internet Traffic Management Practices hearing demonstrated that many market entrants and consumer advocates concur with this assessment. Thus, although Canada could be considered to have facilities-based competition in place if the latter is defined as the mere presence of more than one last mile infrastructure, when the extent of competition is 
measured according to innovative outcomes, it can be concluded that Canada's broadband market does not exhibit 'true' facilities-based competition.

Service-based competition was viewed as a second-best alternative that offers a means of expanding broadband infrastructures by leveraging existing facilities, and that could encourage investment in additional facilities over time. But the 2006 Telecommunications Policy Review Panel (2006, p. 3-35) concluded that "There is no evidence in Canada that the CRTC's "stepping-stone" strategy [support for service-based competition] has provided an effective transition to greater reliance by entrants on their own facilities". As such, it appears that neither facilities- nor service-based competition have been particularly effective in encouraging innovation in the broadband marketplace.

The literature on the impacts of facilities-based competition focuses on its effects in improving broadband penetration rates (Distaso et al., 2006; Höffler, 2007), rather than in creating an innovative market with competitive prices, speeds and service offerings. In the early stages of broadband market development, penetration rates are very important, and initial research naturally focused on how to encourage increased adoption. This paper points out the need to go beyond measuring mere penetration rates. As broadband markets mature and many countries now have established high penetration rates, fostering innovation in broadband service provision should become a more important objective for broadband providers and policy makers than a narrow focus on increasing uptake rates.

Indeed, innovation has become the objective of many governments. Many share the belief that innovation is driven by competition, including the OECD and in Canada the Telecommunications Review Panel (TPRP) (OECD, 2008b; Telecommunications Policy Review Panel, 2006). Further, a recent study by the Berkman Center for Internet \& Society (2009) found 
a correlation between availability of wholesale access through both local loop unbundling and resale, with the availability of high speeds and lower prices. However, it is often not the private sector alone that drives innovation. Policy making bodies around the world are developing strategies to enable the development of higher capacity, next generation technologies to better meet the bandwidth needs of their citizens. They do so by developing broadband policies, and at times by providing subsidies or even investing in, or building networks themselves; possibly through public private partnerships (Lehr, Sirbu, \& Gillett, 2003; Sadowski, Nucianelli, \& De Rooij, 2009) $)^{15}$.

While public investment in a number of places has played an important role in stimulating development of next generation broadband networks, the development of governmental broadband policy and regulation geared towards competition remain key components in further stimulating innovation in the Canadian market. Although additional research is required to identify a full range of policy and regulatory measures to improve competition and innovation, this study has identified two key areas that need attention: policy and regulatory regime and foreign investment policy.

\subsection{Policy and Regulatory Regime}

In order to bring about renewed investment and innovation in the Canadian telecommunications sector, it is first necessary that both the CRTC and Industry Canada acknowledge the problem of limited competition and innovation in the market, and second, that both Industry Canada and the CRTC take a more pro-active role in stimulating market

${ }^{15}$ The extent to which direct public ownership of networks is desirable remains a question however, as processes of liberalization have taught that public ownership of telecommunications networks may generate little incentives to operate efficiently due to the tendency to be bailed out when threatened by bankruptcy (Janssen \& MendysKamphorst, 2008). 
development by policy and regulatory interventions.

As highlighted a number of times in this paper, in its published documents the CRTC often puts forward a very positive assessment of the Canadian broadband market. This includes its 2008 assessment of the communications market (CRTC, 2008a), where the CRTC perceives Canada's broadband uptake very well as compared to other countries. Based on a study by Ofcom from the UK that only compares Canada, the United States, United Kingdom, France, Germany, Italy and Japan, the CRTC concludes that Canada's broadband uptake is high: "Among the countries shown, Canada has the highest proportion of households taking up broadband connections (58\%), followed by Japan, United Kingdom, United States and France, with Italy and Germany lagging. Canada's relatively high take-up rate for broadband service is even more notable in the context of its environment: despite its sprawling geography and low population density, $93 \%$ of Canada's households fell within the broadband footprint in 2006." (CRTC, 2008a, p. 243). Additionally, as noted in previous sections, the CRTC regards prices and speeds offered in Canada to compare favorably from an international perspective, even though OECD numbers, or for that matter a quick comparison among major internet providers in Europe and North America, reveal otherwise. An increasing number of studies indeed point out the need for change in the Canadian broadband market (e.g. Berkman Center for Internet \& Society, 2009; Geist, 2009; St. Arnaud, 2009). Acknowledgment of the need for improvement will be a first step to bringing Canada back to the forefront of global communications.

Second, a more proactive role in policy making (and execution) is desirable. A number of studies have pointed out that broadband development generally thrives in those countries where it is a national priority (Berkman Center for Internet \& Society, 2009; Frieden, 2005). In Canada, broadband policy has received little attention over the last few years. In particular, Industry 
Canada could play a key role in promoting rollout of new last mile infrastructure such as fiber or the licensing of wireless bands. Such engagement may in turn provide a 'competitive threat' to established incumbent DSL and cable providers, encouraging them to invest more in their networks.

Further, it is recommended that the CRTC's mandate to "rely on market forces to the maximum extent feasible as the means of achieving the telecommunications policy objectives" (Governor General in Council, 2006), is revisited. Given the characteristics of the Canadian broadband market described in this paper, and the very limited investment in next generation networks to date (Van Gorp \& Middleton, 2009), relying on market forces alone for the development of next generation broadband networks will likely not be successful. Policy makers could look to other countries, including Singapore, Australia and New Zealand, where governments have decided that they must become more active participants in the development and funding of next generation networks, consistent with what Cava-Ferreruela and AlabauMuñoz (2006) describe as a medium intervention strategy. This is not an entirely new approach for Canada, as its policy makers have always realized, and acted upon, the need to provide services to citizens in locations that commercial providers will not serve. But in recent years, the calls for market forces driven policies have been dominant, to the detriment of Canadians who have not had access to the innovative broadband networks and services that are being developed elsewhere in the world.

\subsection{Foreign Investment}

This study has assessed the state of competition in Canada's broadband market. Although additional research is needed to identify a comprehensive overview of underlying problems to Canada's limited competitive landscape (e.g. problems in local loop unbundling), in order to 
suggest regulatory interventions, one specific recommendation forthcoming from this study is to lift Canada's severe foreign ownership restrictions. These foreign ownership restrictions may contribute to the lack of vigorous competition. Increased foreign investment in the market appears consistent with a competitive market, could easily be encouraged by a change in policy, and could bring about some innovation in the market. Already in 2002, the OECD recommended that Canada lift these restrictions. Similar recommendations were also made in 2006 by the Telecommunications Policy Review Panel (TPRP) (2006), in 2008 by the Competition Policy Review Panel (2008), and echoed recently by Geist (2009) and St. Arnaud (2009). The TPRP, Geist, and St. Arnaud all note Canada's failure to deploy affordable advanced broadband technologies. The TPRP suggests that a more relaxed approach "could consider potential benefits of specific types of [foreign] investments such as promotion of competition, better service and innovation in markets that are not performing as well as they should" (Telecommunications Policy Review Panel, 2006, p. 11-25). However, despite such recommendations, the Telecommunications Act still forbids companies from operating in Canada if they are not owned and controlled by Canadians.

As a result, the CRTC has recently ruled that Globalive Wireless Management, a new mobile operator that acquired advanced wireless service spectrum licenses in 2008, does not currently meet the Canadian ownership requirements and cannot commence operations (CRTC, 2009c). On the bright side, this ruling has sparked renewed calls for changes in Canadian ownership rules. Industry Canada is currently reviewing the case. Incumbent Telus has already responded that it opposes government's overturning of the decision, indicating that changes in foreign ownership rules should be enacted by Parliament, and must apply to all players (Newswire, 2009). 
Whether a market entrant wants to offer mobile services such as Globalive, or wants to enter the fixed line market to collocate, significant investments are needed. In the broadband Internet access area, Canada's competing, yet generally small ISPs predominantly provide wholesale services rather than collocate to offer DSL services. They have thus have been unable to 'climb the ladder investment'. Hence, it is unlikely that they will be able to compete on a large scale with the incumbent telcos and cable companies. Competitors with extensive investment capacity would therefore more likely be established foreign companies. Hence, with no major foreign players in the Canadian telecommunications market, there is likely to be limited investment and thus technological innovation.

\section{Conclusion}

Despite a regulatory regime that should encourage real competition in the marketplace, Canada's comparative decline as a broadband leader has been rapid. This paper demonstrates that Canada's current market structure is not delivering competitive outcomes. The broadband market is dominated by just a few providers, and the services on offer are slower and more expensive than those available in other OECD markets. It is suggested that relying on market forces alone to develop next generation infrastructures in Canada is not likely to be effective, for reasons including lack of foreign investment.

Given the failure of the market to deliver innovative services and next generation networks, the paper calls for a more active role for government (Industry Canada) and the CRTC in stimulating the development of advanced broadband services. Following the recent actions of many countries around the world, broadband policy must be given priority, in order to enhance 
Canada's digital infrastructure, and to ensure that Canadians can participate fully in the information society. Hence, it is imperative that the government and CRTC acknowledge the need for improvement and act upon this by developing policy and regulatory interventions.

This study provides evidence that even though facilities-based competition between cablecos and telcos in the early days in Canada may have been effective in encouraging broadband adoption facilities-based competition was not sustained. These findings suggest that mature broadband markets are different from emerging ones, and hence more research is needed to explore what drives innovation in mature markets rather than merely investigating determinants of adoption.

As the objective of this study was to investigate to the extent to which service-based and facilities based competition exist in the Canadian market, and how these have affected the development of innovative services, a next step is to identify in more detail factors that currently impede competition. Hence, more research is needed that explores the nature of competition and the opportunities and challenges of independent ISPs to provide broadband services. An empirical study of Canada's broadband players, both incumbents and independents (competitors), will enable better identification of policy and regulatory interventions that could be taken by the government and CRTC to stimulate true service-based and facilities-based competition and ensure competitive outcomes. 


\section{References}

Analysys Mason. (2008). Final Report for the Broadband Stakeholder Group - The costs of deploying fibre-based next-generation broadband infrastructure. Cambridge: Broadband Stakeholder Group and Department for Business Enterprise \& Regulatory Reform.

Anderson, S. (2009). Canada needs an innovation agenda. Retrieved 31 May, 2009, from http://www.commonground.ca/iss/215/cg215 anderson.shtml

Atkinson, R. D., Correa, D. K., \& Hedlund, J. A. (2008). Explaining International Broadband Leadership. Washington, DC: The Information Technology and Innovation Foundation.

Baranes, E., \& Bourreau, M. (2005). An Economist's Guide to Local Loop Unbundling. Communications \& Strategies, 57(1), 13-31.

Beard, T. R., Ford, G. S., \& Spiwak, L. J. (2009). The Broadband Adoption Index: Improving Measurements and Comparisons of Broadband Deployment and Adoption (Phoenix Center Policy Paper Number 36). Washington, DC: Phoenix Center for Advanced Legal and Economic Public Policy Studies.

Bell Aliant. (2009). Bell Aliant, in partnership with Government of New Brunswick, to be first in Canada to launch fibre to the home to an entire city. Retrieved 25 July, 2009, from http://bellaliant.ca/english/news/view_art.asp?id=1888

Berkman Center for Internet \& Society. (2009). Draft (October 2009) - Next Generation Connectivity: A review of broadband Internet transitions and policy from around the world: The Berkman Center for Internet \& Society at Harvard University. Downloaded from http://www.fcc.gov/stage/pdf/Berkman_Center_Broadband_Study_13Oct09.pdf.

Bode, K. (2009). Bell Canada Lowers Broadband Caps. Retrieved 10 August, 2009

Borenstein, S., Bushnell, J., \& Knittel, C. R. (1999). Market power in electricity markets: Beyond concentration measures: Program on Workable Energy Regulation (POWER), Working Paper PWP-059r. Downloaded from http://www.ucei.berkeley.edu/ucei/PDF/pwp059r.pdf.

Bouckaert, J., van Dijk, T., \& Verboven, F. (2008). How does access regulation affect broadband penetration? Retrieved 21 March, 2009, from http://www.voxeu.eu/index.php?q=node/2715

Bouras, C., Giannaka, E., \& Tsiatsos, T. (2009). Identifying best practices for supporting broadband growth: Methodology and analysis. Journal of Network and Computer Applications, 32, 795-807.

Bourreau, M., \& Dogan, P. (2004). Service-based vs. facility-based competition in local access networks. Information Economics and Policy, 16(2), 287-306

Braverman, B., \& Frappier, D. (2003). Digital Must-Carry and Forced Access: GovernmentMandated Access to Cable Distribution Networks in the US and the EU. Communications \& Strategies, 49(1), 43-66.

Broadband Stakeholder Group. (2007). Pipe Dreams?: Prospects for next generation broadband 
deployment in the UK. Retrieved 9 November, 2008, from www.broadbanduk.org/content/view/236/7/

Brown, G. (2009, 16 June). The internet is as vital as water and gas; Every home will have broadband access as we aim for a digital Britain fit to take on the world. The Times, p. 24,

California Broadband Task Force. (2008). The State of Connectivity - Building Innovation Through Broadband: State of California.

Canada. (1993). Telecommunications Act, S.C., 1993, C. 38. Available at http://laws.justice.gc.ca/PDF/Statute/T/T-3.4.pdf.

Canadian Association of Internet Providers. (2003). The Canadian ISP Count, 2003: How many, where they are and what they do. Canadian Association of Internet Providers (CAIP).

Cava-Ferreruela, I., \& Alabau-Muñoz, A. (2006). Broadband policy assessment: A cross-national empirical analysis. Telecommunications Policy, 30(8-9), 445-463.

Cave, M. (2006). Encouraging infrastructure competition via the ladder of investment. Telecommunications Policy, 30(3-4), 223-237.

Chretien, J. (2000). Connecting Canadians: Message from the Prime Minister of Canada. Retrieved 25 September, 2005, from http://web.archive.org/web/20031212231625/www.connect.gc.ca/en/ar/1016-e.asp

Christodoulou, K., \& Vlahos, K. (2001). Implications of regulation for entry and investment in the local loop. Telecommunications Policy, 25, 743-757.

CompetitionPolicyReviewPanel. (2008). Compete to win - final report June 2008. . Public Works and Government Services Canada, Ottawa. Retrieved 1 December 2009 from http://www.ppforum.ca/sites/default/files/Compete to_Win.pdf.

Computer Science and Telecommunications Board. (2002). Broadband: Bringing Home the Bits. Washington, DC: National Academy Press.

CRTC. (1997). Telecom Decision CRTC 97-08: Local Competition. Retrieved 14 March, 2009, from http://www.crtc.gc.ca/eng/archive/1997/DT97-8.HTM

CRTC. (1999). Telecom Decision 99-11: Application concerning access by Internet service providers to incumbent cable carriers' telecommunications facilities. Retrieved 14 March, 2009, from http://www.crtc.gc.ca/eng/archive/1999/DT99-11.HTM

CRTC. (2001a). Telecom Decision CRTC 2001-204. Retrieved 19 May, 2009, from http://www.crtc.gc.ca/eng/archive/2001/DT2001-204.htm

CRTC. (2001b). Telecom Decision CRTC 2001-238: Restructured bands, revised loop rates and related issues. Retrieved 19 May, 2009, from http:/www.crtc.gc.ca/eng/archive/2001/DT2001-238.htm

CRTC. (2003). Telecom Decision CRTC 2003-87: Application by Cybersurf seeking resale of Shaw higher-speed retail Internet service. Retrieved 19 May, 2009, from http://www.crtc.gc.ca/eng/archive/2003/dt2003-87.pdf

CRTC. (2004). Telecom Decision CRTC 2004-24: Cybersurf Corp. v. Shaw Cablesystems G.P. Enforcement of Telecom Decision CRTC 2003-87. Retrieved 19 May, 2009, from 
http://www.crtc.gc.ca/eng/archive/2004/dt2004-24.htm

CRTC. (2006). Telecom Decision CRTC 2006-77: Cogeco, Rogers, Shaw, and Videotron Third-party Internet access service rates. Retrieved 19 May, 2009, from http://www.crtc.gc.ca/eng/archive/2006/dt2006-77.pdf

CRTC. (2008a). Communications Monitoring Report. Ottawa: Canadian Radio-television and Telecommunications Commission.

CRTC. (2008b). Public notice CRTC 2008-19: Notice of consultation and hearing - Review of the Internet traffic management practices of Internet service providers Retrieved 1 June, 2009, from http://www.crtc.gc.ca/eng/archive/2008/pt2008-19.htm

CRTC. (2008c). Telecom Decision CRTC 2008-108: The Canadian Association of Internet Providers' application regarding Bell Canada's traffic shaping of its wholesale Gateway Access Service. Retrieved 19 May, 2009, from http://www.crtc.gc.ca/eng/archive/2008/dt2008-108.pdf

CRTC. (2009a). Communications Monitoring Report. Ottawa: Canadian Radio-television and Telecommunications Commission.

CRTC. (2009b). Telecom Commission Letter Re: Part VII applications by TCC, Bell Aliant and Bell Canada to stay Telecom Decision 2008-117 and Telecom Order 2009-111 Retrieved 1 June, 2009, from http://www.crtc.gc.ca/eng/archive/2009/1t090316a.htm

CRTC. (2009c). Telecom decision CRTC 2009-678: Review of Globalive Wireless Management Corp. under the Canadian ownership and control regime. Retrieved 28 November 2009 from http://www.crtc.gc.ca/eng/archieve/2009/2009-678.htm

CRTC. (2009d, 14 March 2009). Telecom Order CRTC 2009-111: Cybersurf's application related to the implementation of Telecom Decision 2008-117 regarding the matching speed requirement. Retrieved 14 March, 2009, from http://www.crtc.gc.ca/eng/archive/2009/2009-111.htm

CRTC. (2009e). Telecom regulatory policy CRTC 2009-657: Review of the Internet traffic management practices of Internet Service Providers, 21 October 2009. Downloaded 3 December 2009 from http://www.crtc.gc.ca/eng/archive/2009/2009-657.htm.

de Bijl, P., \& Peitz, M. (2008). Innovation, convergence and the role of regulation in the Netherlands and beyond. Telecommunications Policy, 32, 744-754.

Denni, M., \& Gruber, H. (2007). The Diffusion of Broadband Telecommunications in the US: The Role of Different Forms of Competition. COMMUNICATIONS AND STRATEGIES, $68,139-158$.

Department for Culture Media \& Sport, \& Department for Business Enterprise \& Regulatory Reform. (2009). Digital Britain - The Interim Report. Norwich: TSO.

Department for Culture Media and Sport, \& Department for Business Innovation and Skills. (2009). Digital Britain - Final Report June 2009. Kew, Richmond, Surrey: Office of Public Sector Information.

Department of Broadband Communications and the Digital Economy. (2009). Australia's Digital Economy: Future Directions. Canberra: Commonwealth of Australia. 
Distaso, W., Lupi, P., \& Manenti, F. M. (2006). Platform competition and broadband uptake: Theory and empirical evidence from the European Union. Information Economics and Policy, 18(1), 87-106.

Epitiro. (2009). Australia Internet Performance Index - Summary Findings 2008 (Q4). Sydney: Epitiro.

European Regulators Group (2005). Broadband market competition report. Journal. Retrieved from http://www.erg.eu.int/doc/publications/erg_05 23 broadbd_mrkt_comp report p.pdf

Ezell, S., Atkinson, R., Castro, D., \& Ou, G. (2009). The Need for Speed: The Importance of Next-Generation Broadband Networks. Washington, DC: The Information Technology and Innovation Foundation.

Falch, M., \& Henten, A. (2008). Investment dimensions in a universal service perspective: next generation networks, alternative funding mechanisms and public-private partnerships. info, 10(5/6), 33-45.

Federal-State Joint Board on Universal Service. (2007). Recommended Decision in the Matter of High-Cost Universal Service Support: Federal Communications Commission.

Federal Communications Commission. (2009). FCC Launches Development of National Broadband Plan. Retrieved 12 April, 2009, from http://hraunfoss.fcc.gov/edocs_public/attachmatch/DOC-289900A1.pdf

Ford, G. S., Koutsky, T. M., \& Spiwak, L. J. (2007). The Broadband Performance Index: A Policy-Relevant Method of Comparing Broadband Adoption Among Countries (Phoenix Center Policy Paper Number 29). Washington, DC: Phoenix Center for Advanced Legal and Economic Public Policy Studies.

Frieden, R. (2005). Lessons from broadband development in Canada, Japan, Korea and the United States. Telecommunications Policy, 29(8), 595-613.

Geist, M. (2009). In search of a Canadian digital action strategy. Ottawa.

Governor General in Council (2006). Order Issuing a Direction to the CRTC on Implementing the Canadian Telecommunications Policy Objectives. Journal, 140(26), 2344-2349. Retrieved from http://canadagazette.gc.ca/archives/p2/2006/2006-12-27/html/sordors355-eng.html

Hartley, M. (2008, 26 March). Bell to play traffic cop on Internet bandwidth. The Globe and Mail, p. B5,

Higginbotham, S. (2009). DOCSIS 3.0: Coming Soon to a Cableco Near You. Retrieved 3 June, 2009, from http://gigaom.com/2009/04/30/docsis-30-coming-soon-to-an-isp-near-you/

Höffler, F. (2007). Cost and benefits from infrastructure competition. Estimating welfare effects from broadband access competition. Telecommunications Policy, 31(6-7), 401-418.

Huigen, J., \& Cave, M. (2008). Regulation and the promotion of investment in next generation networks - A European dilemma. Telecommunications Policy, 32, 713-721.

Industry Canada. (2005a). Broadband - The Programs - Broadband for Rural and Northern Development - About Us. Retrieved 10 May, 2007, from 
http://web.archive.org/web/20070820172711/http://broadband.gc.ca/pub/program/about.h $\underline{\mathrm{tml}}$

Industry Canada. (2005b). Broadband - The Programs - National Satellite Initiative - About Us. Retrieved 24 August, 2005, from http://web.archive.org/web/20070820172822/http://broadband.gc.ca/pub/program/nsi/abo utus.html

Industry Canada. (2009a). Broadband Canada: Connecting Rural Canadians - About the Program. Retrieved 28 July, 2009, from http://www.ic.gc.ca/eic/site/719.nsf/eng/h_00001.html

Industry Canada. (2009b). Broadband Canada: Connecting rural Canadians launches its Callfor-Applications process. Ottawa. Retrieved from http://www.ic.gc.ca/eic/site/ic1.nsf/eng/04943.html.

Industry Canada. (2009c). Broadband Program. Retrieved 8 May, 2009, from http://www.ic.gc.ca/eic/site/719.nsf/eng/home

Infocomm Development Authority of Singapore. (2008). Singapore's Next Generation National Broadband Network To Be Nationwide by 2012. Retrieved 20 May, 2009, from http://www.ida.gov.sg/News\%20and\%20Events/20080926174755.aspx? getPagetype=20

Information Highway Advisory Council. (1996). Building the information society: moving Canada into the 21st century. Ottawa, ON: Industry Canada.

Information Highway Advisory Council. (1997). Preparing Canada for a digital world: Final report of the Information Highway Advisory Council. Ottawa: Industry Canada.

International Telecommunication Union. (2008). Asia-Pacific Telecommunication/ICT Indicators 2008: Broadband in Asia-Pacific: too much, too little? Geneva: International Telecommunication Union.

International Telecommunication Union. (2009). Measuring the Information Society - The ICT Development Index. Geneva: International Telecommunication Union.

Janssen, M. C. W., \& Mendys-Kamphorst, E. (2008). Triple play: How do we secure future benefits? Telecommunications Policy, 32, 735-743.

KBS World. (2009). Information Ultra Highway. Retrieved 24 May, 2009, from http://world.kbs.co.kr/english/news/news_science_detail.htm?no=4360

Lehr, W., Sirbu, M., \& Gillett, S. (2003). Broadband open access: Lessons from municipal network case studies. Paper presented at the TPRC.

Li, W., Qiang, C. Z.-W., \& Xu, L. C. (2001). The political economy of privatization and competition: Cross-country evidence from the telecommunications sector: CEPR Discussion Paper No. 2825.

Manley, J. (1999). Speech: Canada and the Internet Revolution: Connecting Canadians. Retrieved 13 October, 2005, from http://www.trilateral.org/annmtgs/trialog/trlgtxts/t53/man.htm

Mark H. Goldberg \& Associates Inc. (2009). Lagging or leading: The state of Canada's broadband infrastructure. Downloaded 3 December 2009 from 
http://www.gstconferences.com/LagOrLead.pdf.

Market Clarity. (2007). Broadband Wars: The OECD's International Broadband Arms Race. Sydney.

Ménard, F. D. (2006). The New Economics of Fiber: Xittel Combines Fiber and Motorola WiMAX to Serve as Few as 25 Customers. Broadband Properties, December, 32-37.

Menard, F. D., \& Denton, T. (1999). Third party access to cable modems in Canada. Downloaded March 5, 2009 from http://www.tmdenton.com/pub/articles/thirdparty access.pdf.

Moll, M. (2008). Communications for Social and Economic Development - A National Inclusion Strategy for Broadband Connectivity and Effective Public Use. Proposal to the 2009 Alternative Federal Budget Process (Canadian Centre for Policy Alternatives). Retrieved 31 May, 2009, from http://www.tc.ca/alt-fed-bud.html

Moll, M., \& Shade, L. R. (Eds.). (2008). For Sale To The Highest Bidder : Telecom Policy In Canada. Ottawa: Canadian Centre for Policy Alternatives.

National Broadband Task Force. (2001). The New National Dream: Networking the Nation for Broadband Access. Ottawa: Industry Canada.

National Telecommunications and Information Administration. (2009). Broadband Technology Opportunities Program - Notice of Funds Availability Fact Sheet. Retrieved 28 July, 2009, from http://www.ntia.doc.gov/broadbandgrants/BTOP_NOFAfactsheet 090702.pdf

Newswire. (2009). Telus urges caution with Globalive decision. Published 18 November 2009. Retrieved 2 december 2009 from http://www.newswire.ca/en/releases/archive/November2009/18/c2412.html

NTIA. (2009). Broadband Technology Opportunities Program. Retrieved from http://www.ntia.doc.gov/broadbandgrants/.

OECD. (2002). OECD Reviews of Regulatory Reform - Regulatory Reform in Canada: From Transition to New Regulation Challenges. Paris: OECD.

OECD. (2008a). Average advertised broadband download speed, by country, Mbit/s, October 2007. OECD Broadband Statistics

OECD. (2008b). Broadband growth and policies in OECD countries. Paris: OECD.

OECD. (2009a). Average advertised broadband download speed, by country, Kbit/s, September 2008. OECD Broadband Statistics Retrieved 24 May, 2009, from http://www.oecd.org/dataoecd/10/53/39575086.xls

OECD. (2009b). Average broadband monthly price per advertised Mbit/s, USD PPP, October 2008. OECD Broadband Statistics Retrieved 24 May, 2009, from http://www.oecd.org/dataoecd/22/45/39575011.xls

OECD. (2009c). Average monthly bit/data cap size and price per additional MB, by country, October 2008. OECD Broadband Statistics Retrieved 3 June, 2009, from http://www.oecd.org/dataoecd/22/46/39575020.xls 
OECD. (2009d). Broadband subscribers per 100 inhabitants, December 2008. Retrieved 31 May, 2009, from http://www.oecd.org/dataoecd/21/35/39574709.xls

OECD. (2009e). OECD Broadband Portal. Retrieved 8 January, 2009, from www.oecd.org/sti/ict/broadband

OECD. (2009f). OECD communications outlook. Paris: OECD.

OECD. (2009g). Percentage of fibre connections in total broadband among countries reporting fibre subscribers, December 2008. OECD Broadband Statistics Retrieved 24 May, 2009, from http://www.oecd.org/dataoecd/21/58/39574845.xls

OECD Directorate for Science Technology and Industry. (2001). The Development of Broadband Access in OECD Countries. Paris: OECD.

OECD Directorate for Science Technology and Industry. (2003a). Broadband and Telephony Services Over Cable Television Networks. Paris: OECD.

OECD Directorate for Science Technology and Industry. (2003b). Broadband Driving Growth: Policy Responses. Paris: OECD.

OECD Directorate for Science Technology and Industry. (2003c). Developments in local loop unbundling. Paris: OECD.

OECD Directorate for Science Technology and Industry. (2008a). Developments in Fibre Technologies and Investment. Paris: OECD Working Party on Communication Infrastructures and Services Policy.

OECD Directorate for Science Technology and Industry. (2008b). OECD Policy Guidance on Convergence and Next Generation Networks. Seoul: OECD Ministerial Meeting on the Future of the Internet Economy.

Ofcom. (2009). UK broadband speeds 2008.

OPTA. (1999). Guidelines on access to the unbundled local loop ('MDF-access'): OPTA. 16 March 1999. http://www2.opta.nl/download/mdfeng.pdf.

Organisation for Economic Co-operation and Development. (2009). OECD Broadband subscriptions, by technology, December 2008. Retrieved 26 July, 2009, from http://www.oecd.org/dataoecd/11/20/39575781.xls

Ovum (2006). International Broadband Market Comparisons Update March 2006 - Covering the period October-December 2005, Available from http://www.berr.gov.uk/files/file29469.pdf

Picot, A., \& Wernick, C. (2007). The role of government in broadband access. Telecommunications Policy, 31(10-11), 660-674.

Polykalas, S. E., \& Vlachos, K. G. (2006). Broadband penetration and broadband competition: evidence and analysis in the EU market. Info, 8(6), 15-30.

Prime Minister of Australia. (2009). New National Broadband Network. Retrieved 10 April, 2009, from http://www.pm.gov.au/media/Release/2009/media release 0903.cfm

Quast, T. (2008). Did federal regulation discourage facilities-based entry into US local telecommunications markets? Telecommunications Policy, 32(8), 572-581. 
Quigley, N. (2004). Dynamic Competition in Telecommunications: Implications for Regulatory Policy. Toronto: C. D. Howe Institute.

Reynolds, T. (2009). The Role of Communication Infrastructure Investment in Economic Recovery: Organisation for Economic Co-operation and Development.

Sadowski, B., Nucianelli, A., \& De Rooij, M. (2009). Providing incentives for private investment in municipal broadband networks: Evidence from the Netherlands. Telecommunications Policy, 33(10-11), 582-595.

Schwarz, A. (2007). Wholesale market definition in telecommunications: The issue of wholesale broadband access. Telecommunications Policy, 31(5), 251-264.

St. Arnaud, B. (2009). Bill St. Arnaud on the state of Canadian broadband: Interview with Nora Young on Spark. Retrieved 1 December 2009 from http://www.cbc.ca/spark/2009/06/full-interview-bill-st-arnaud-on-the-state-of-canadianbroadband/

Telecommunications Policy Review Panel. (2006). Telecommunications Policy Review Panel Final Report 2006. Ottawa: Industry Canada.

The Consumers' Association of Canada, Canada Without Poverty, The Canadian Association of Internet Providers, Acanac Inc., Accelerated Connections Inc., Cybersurf Corp., et al. (2009). Part VII Application To Review and Vary Telecom Decision CRTC 2008-108, Canadian Association of Internet Providers - Application requesting certain orders directing Bell Canada to cease and desist from throttling its wholesale ADSL Access Services. Retrieved 2 June, 2009, from http://www.cata.ca/files/CAIP/R_V_on_Throttling_(20May09FINAL)-1.pdf

Troulos, C. (2008). Greek National Strategy for Fiber Access Networks. Retrieved 20 May, 2009, from http://broadbandprime.blogspot.com/2008/09/greek-national-strategy-forfiber.html

UNCTAD Secretariat. (2007). Information Economy Report 2007-2008 - Science and Technology for Development: The New Paradigm of ICT. New York and Geneva: United Nations Conference on Trade and Development.

Van Cuilenburg, J., \& Slaa, P. (1995). Competition and innovation in telecommunications: An empirical analysis of innovative telecommunications in the public interest. Telecommunications Policy, 19(8), 647-663.

Van Gorp, A. F., Maitland, C. F., \& Hanekop, H. (2006). The broadband Internet access market: The changing role of ISPs. Telecommunications Policy, 30(2), 96-111.

Van Gorp, A. F., \& Middleton, C. (2009). Fiber to the Home and Competition: Developments in the Netherlands and Canada. Paper presented at the The 37th Research Conference on Communication, Information and Internet Policy (TPRC).

Verizon Communications. (2008). 2008 Annual Report. New York.

Verizon Communications. (2009). Verizon Communications Reports Revenue, Earnings and Cash Flow Growth in 1Q 2009. Retrieved 28 July, 2009

Whalley, J., \& Curwen, P. (2008). Equality of access and local loop unbundling in the UK 
broadband telecommunications market. Telematics and Informatics, 25(4), 280-291.

Wu, I. (2004). Canada, South Korea, Netherlands and Sweden: regulatory implications of the convergence of telecommunications, broadcasting and Internet services.

Telecommunications Policy, 28, 79-96. 